\title{
ADAPTATION OF MAHONEY, TYPE I, POLIOMYELITIS VIRUS TO SUCKLING MICE
}

\author{
By GOLDA SELZER \\ The C.S.I.R.O. and U.C.T. Virus Research Unit, Department of Pathology, \\ University of Cape Town (South Africa)
}

(With 2 Figures in the Text)

Several attempts have been made in our laboratory to adapt the Type 1 poliomyelitis virus to suckling mice so that it would multiply rapidly and produce early paralysis in mice of that age. Most of these attempts have been unsuccessful even when methods were employed such as led to successful adaptation of the MEF Type 3, strain of poliomyelitis to suckling mice (Selzer, Sacks \& van den Ende, 1952). The adapted $\mathrm{MEF}_{1}$ virus is characterized by its rapid, early multiplication in the brains of infant mice, the invariable paralysis within 24-34 hrs. of inoculation and the high virus content in infected brains.

Titration of virus in the brains of suckling mice which had received a single injection of Type 1 (Mahoney) virus not adapted to infant mice revealed that multiplication occurred even though the mice showed no signs of illness. The maximum virus content was found approximately $48 \mathrm{hr}$. after inoculation. A toand-fro passage of virus into suckling mice and tissue culture ultimately led to 'adaptation', so that paralysis of suckling mice occurred in 2-4 days after intracerebral inoculation of the adapted virus.

\section{MATERIALS AND METHODS \\ Virus}

The virus used was the Mahoney strain received from Dr Stanley, Australia. It had been through 71 CNS-passages in adult mice in his laboratory.

\section{Mice}

Both the Prince Henry strain received from Dr Stanley and the Onderstepoort strain of albino mice bred in our laboratory were used. They were inoculated intracerebrally when 4-5 days old. The two strains proved equally susceptible to the virus.

\section{Tissue culture}

Trypsin digests of monkey kidney were prepared by the method of Melnick, Rappaport, Banker \& Bhatt (1955). These cells were cultured in test tubes, each one receiving $6 \times 10^{5}$ cells in $1 \mathrm{ml}$. of nutrient. Nutrient consisted of either bovine amniotic fluid or Hanks' solution with $5 \%$ beef embryo extract and $5 \%$ horse serum. 


\section{Titrations in tissue culture}

Serial ten-fold dilutions of $10 \%$ mouse brain suspension or tissue culture fluids were prepared in Hanks' solution. Each dilution was inoculated into tissue culture, using two tubes per dilution and a dose of $0 \cdot 1 \mathrm{ml}$. per tube. The cells were observed daily for 10 days for cytopathogenic changes. Titration endpoints were expressed as $\log \mathrm{ID}_{50}$ per ml.

\section{Adaptation to mice}

Each of a number of suckling mice received intracerebrally $0.02 \mathrm{ml}$. of Mahoney virus which had been passaged in tissue culture. At different times groups of three mice were chosen at random and killed with ether. Their brains and cords were harvested, pooled, ground with glass powder and a $10 \%$ suspension made in Hanks' solution containing $10 \%$ rabbit serum. This was spun at 3000 r.p.m. for $\mathbf{l ~ h r}$. in a refrigerated centrifuge and the supernatant fluid used for passage and for titration in tissue culture.

The observation that multiplication of virus took place in suckling mouse brains, and that the maximum virus content was reached $48 \mathrm{hr}$. after intracerebral inoculation led to attempts at adaptation by two different methods. The first consisted of continuous passage from mice to mice of mouse brains and cords harvested $48 \mathrm{hr}$. after inoculation of suckling mice.

The second employed to-and-fro passage from mice to tissue culture and back to mice, etc. The brains and cords of infected mice, either selected at random, or chosen because of paralysis, were collected $48 \mathrm{hr}$. after inoculation, two mice being chosen from each litter inoculated and the remainder of the litters observed for a period of 21 days. The brains from each group of mice killed were pooled and titrated in tissue culture. The contents of the tubes which had received the undiluted inoculum were collected when they showed cytopathogenic effect and were used for inoculation of the next batch of mice. After $48 \mathrm{hr}$. representative mice from the next passage were killed and their brains and cords used for the next tissue culture passage and also inoculated into another batch of suckling mice. The tissue culture fluid used for inoculation into mice was titrated both in tissue culture and suckling mice from time to time. In one experiment the contents of tissue culture tubes showing cytopathogenic effect with the highest dilution of inoculum (limit dilution) was used for passage to baby mice. The results of this experiment did not differ significantly from those of the usual experiments.

When virus, adapted to the brains of suckling mice, became available, its rate of multiplication in infant mouse brains was determined. The virus was also inoculated intracerebrally into groups of mice varying in age from 2 to 18 days to determine any difference in age susceptibility.

\section{Neutralization tests}

Neutralization tests were carried out using Types 1 and 2 monkey poliomyelitis immune serum received from Dr H. Malherbe, Poliomyelitis Research Foundation, Johannesburg. The serum was diluted 1 in 5 and added to an equal 
volume of fluid containing $1000 \mathrm{TCID}_{50}$ of virus. This was left at room temperature for $1 \mathrm{hr}$. and then inoculated into tissue culture tubes. The tubes were observed daily for 10 days for the development of cytopathogenic changes.

\section{RESULTS}

\section{Multiplication of unadapted Type I poliomyelitis virus in brains of suckling mice}

One hour after intracerebral inoculation into mice of tissue culture virus, which had a titre of $10^{3.5} \mathrm{TCID}_{50} / \mathrm{ml}$. the virus content of the brains of recipient mice was only $10^{0.5} \mathrm{TCID}_{50} / \mathrm{ml}$. There was, however, a rapid multiplication of virus commencing within the first $24 \mathrm{hr}$. after inoculation and reaching a maximum at about $48 \mathrm{hr}$. (Fig. $1 B$ ). At this time the titre as estimated in tissue culture was at least that of the original inoculum $\left(10^{3.5} \mathrm{TCID}_{50} / \mathrm{ml}\right.$. of $10 \%$ brain emulsion). The mice, however, showed no evidence of abnormality. By the fourth day the titre had dropped to $10^{1 \cdot 5} \mathrm{TCID}_{50} / \mathrm{ml}$. Paralysis appeared about 9-14 days after inoculation in about $40 \%$ of mice. When the titre of the inoculum was higher $\left(10^{5-8}\right)$ a similar result was obtained (Fig. $1 \mathrm{~A}$ ) except that the onset of paralysis was earlier.

\section{Adaptation to suckling mice}

In the first attempt at adaptation by successive mouse-to-mouse passage there appeared to be a gradual reduction in the amount of virus detected $48 \mathrm{hr}$. after inoculation. Thus the virus titre attained in brains of the first passage was $10^{3 \cdot 5} \mathrm{TCID}_{50} / \mathrm{ml}$. of $10 \%$ brain emulsion, whereas after four passages virus was no longer detectable $48 \mathrm{hr}$. after intracerebral inoculation.

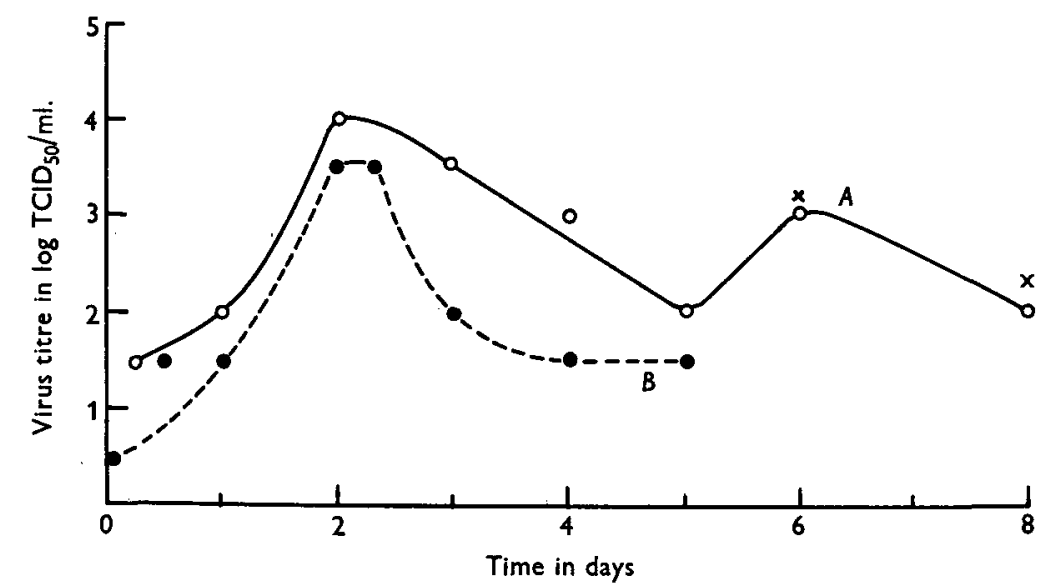

Fig. 1. Multiplication rate of unadapted Mahoney, Type I, poliomyelitis virus in the brains of suckling mice. $A, \mathrm{O}-\mathrm{O}$, Titre of inoculum was $10^{5.5} \mathrm{TCID}_{50} / \mathrm{ml} . B, \bullet \cdots$, Titre of inoculum was $10^{3.5} \mathrm{TCID}_{50} / \mathrm{ml}$. $\times$ denotes paralysis of mice.

Successive mouse-to-mouse passage was later attempted in suckling mice using also 'adapted' Type I virus, with a tissue culture titre of $10^{6} \mathrm{TCID}_{50} / \mathrm{ml}$. as the initial inoculum. Only in the first passage were a significant number of mice. 
paralysed within 4 days of inoculation. In subsequent passages the number of mice paralysed was negligible, and by the fifth passage virus was not detectable $48 \mathrm{hr}$. after intracerebral inoculation, and none of the mice developed paralysis.

The second method of adaptation, that of to-and-fro mouse-tissue culture passage, was successful (Table 1). The inoculum for the first passage was the fluid collected from tissue culture which had been infected with virus from brains of suckling mice $48 \mathrm{hr}$. after intracerebral inoculation of the unadapted virus. Table 1 shows the steady rise in the amount of virus produced during the early

\begin{tabular}{|c|c|c|c|c|c|}
\hline $\begin{array}{l}\text { No. of } \\
\text { alternate } \\
\text { aouse and } \\
\text { tissue } \\
\text { culture } \\
\text { passages }\end{array}$ & $\begin{array}{l}\text { No. of mice } \\
\text { inoculated }\end{array}$ & $\begin{array}{l}\text { Titre of TCF } \\
\text { inoculum* }\end{array}$ & $\begin{array}{c}\% \text { mice } \\
\text { paralysed } \\
\text { within 4 days }\end{array}$ & $\begin{array}{c}\% \text { mice } \\
\text { paralysed } \\
\text { within } 21 \text { days }\end{array}$ & $\begin{array}{l}\text { Virus content } \\
\text { of mouse brains } \\
48 \mathrm{hr} \text {. after } \\
\text { inoculation } \dagger\end{array}$ \\
\hline 1 & 18 & - & 44 & 78 & $10^{3.5}$ \\
\hline 2 & 23 & 一 & 52 & 78 & $10^{3.5}$ \\
\hline 3 & 24 & $10^{6}$ & 46 & 92 & $10^{4.5}$ \\
\hline 4 & 24 & $10^{6}$ & 58 & 100 & $10^{4.5}$ \\
\hline 5 & 26 & $10^{7.0}$ & 88 & 100 & $10^{4.5}$ \\
\hline 6 & 31 & $10^{5.5}$ & 77 & 94 & $10^{4.5}$ \\
\hline 7 & 48 & - & 69 & 92 & $10^{5.0}$ \\
\hline 8 & 40 & $10^{5.5}$ & 81 & 91 & $10^{5 \cdot 5}$ \\
\hline
\end{tabular}

multiplication cycle in suckling mouse brains by this to-and-fro mouse-tissue culture method, and the increased incidence of paralysis, especially early paralysis, in suckling mice in the later passages.

It is of interest that several of the mice which became paralysed in this experiment survived for many months in spite of persistent paralysis. This is in striking contrast to the $\mathrm{MEF}_{1}$ virus, which once it has produced paralysis is invariably fatal.

Passage of brains and cords of paralysed mice into further suckling mice, without the intermediate passage of tissue culture, repeatedly failed to produce early paralysis except in an occasional suckling mouse. Thus an emulsion of brains and cords harvested from sucklings paralysed within $48 \mathrm{hr}$. of intracerebral inoculation of eighth passage virus had a tissue culture titre of $10^{5.5} \mathrm{TCID}_{50} / \mathrm{ml}$. of $10 \%$ brain suspension. This brain suspension was inoculated into seventy-four suckling mice. Despite the high titre of the inoculum only five mice developed paralysis within 4 days of inoculation and on each of the eleventh, twelfth and thirteenth days after inoculation paralysis was noted in two of the sucklings.

That a high concentration of virus is required to produce a high percentage of early paralysis, even when alternate mouse-tissue culture passage is employed, is shown by the results recorded in Table 2 . These results show that an inoculum with a tissue-culture infective-titre of $10^{6}$ produces paralysis within 4 days in a 
large proportion of mice. The $10^{-1}$ dilution of the same inoculum produced paralysis in only $50 \%$ of sucklings, whilst $10^{-2}$ failed to produce paralysis except in an occasional mouse.

Table 2. Titration of Mahoney, Type I, tissue culture virus (Titre $10^{6}$ TCID $_{50}$ / ml.) in suckling mice

\begin{tabular}{ccc}
$\begin{array}{c}\text { Tissue culture fluid } \\
\text { virus dilution }\end{array}$ & $\begin{array}{c}\text { No. of mice } \\
\text { inoculated }\end{array}$ & $\begin{array}{c}\% \text { of mice paralysed } \\
\text { within } 4 \text { days }\end{array}$ \\
$10^{0}$ & 63 & 78 \\
$10^{-1}$ & 16 & 50 \\
$10^{-2}$ & 14 & 7 \\
\multicolumn{3}{c}{ Multiplication of adapted Type 1 poliomyelitis virus in } \\
brains of suckling mice
\end{tabular}

Virus obtained after six alternate brain-tissue culture passages was inoculated intracerebrally into fifty-one mice aged 4-5 days. The inoculum had a titre in tissue culture of $10^{6} \mathrm{TCID}_{50} / \mathrm{ml}$. At the end of $6 \mathrm{hr}$. the amount of virus present in brain tissue was $10^{2 \cdot 5} \mathrm{TCID}_{50} / \mathrm{ml}$. of $10 \%$ brain emulsion. Multiplication had occurred within 24-30 hr. and a maximum concentration was reached in $48 \mathrm{hr}$.

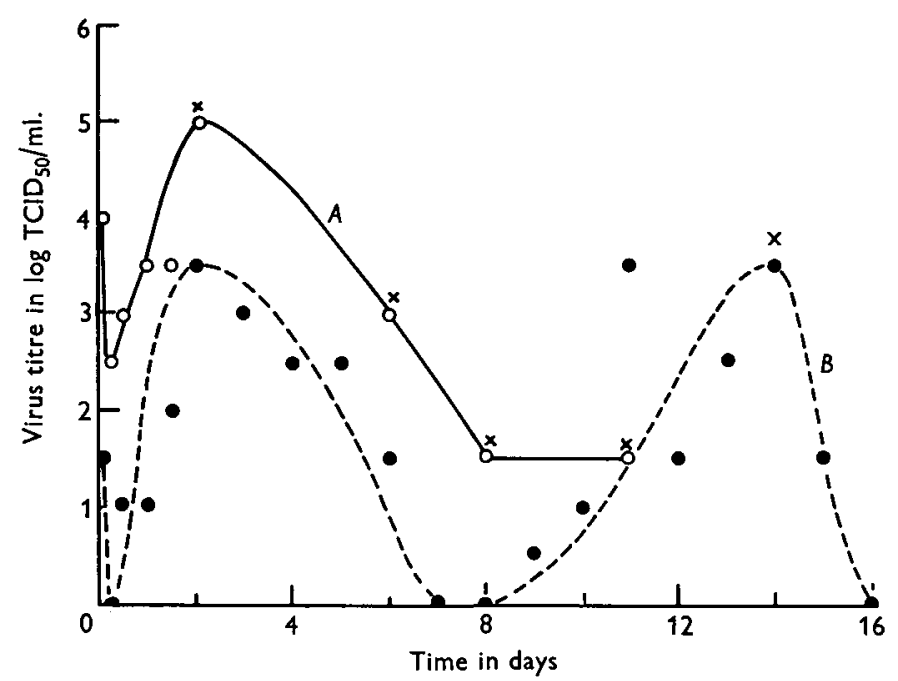

Fig. 2. Multiplication rate of adapted Mahoney, Type I, poliomyelitis virus in the brains of suckling mice. $A, \mathrm{O}-\mathrm{O}$, Titre of inoculum was $10^{6} \mathrm{TCID}_{50} / \mathrm{ml} . B,-\cdots$, Titre of inoculum was $10^{4}$ TCID $_{50} / \mathrm{ml}$. $\times$ denotes paralysis of mice.

$\left(10^{5} \mathrm{TCID}_{50} / \mathrm{ml}\right.$. of $10 \%$ brain emulsion $)$. One-third of the mice were paralysed $48 \mathrm{hr}$. after the inoculation; during the next 3 days a further $30 \%$ developed paralysis. All except four of the remainder developed paralysis at irregular intervals over a period of 21 days. The amount of virus present in mice paralysed on the sixth, eighth and eleventh days after inoculation was considerably lower than in those paralysed $48 \mathrm{hr}$. after inoculation (Fig. $2 \mathrm{~A}$ ). 
The experiment was repeated with the original inoculum diluted a hundred-fold so that it contained $10^{4} \mathrm{TCID}_{50} / \mathrm{ml}$. The inoculum was given to 128 mice aged 4-5 days and the virus content of the brains of mice selected at random during the succeeding 16 days determined. The results (Fig. $2 B$ ) are similar to those obtained with the unadapted virus. Only one of the 128 mice developed paralysis (on the fourteenth day) during the observation period of 21 days.

Table 3 shows the results of intracerebral inoculation of 'adapted' Type 1 poliomyelitis virus, into mice of different ages. From these results it appears that mice reach their maximum susceptibility to early paralysis at the age of 6-8 days, but the amount of virus present in the CNS does not differ significantly in any of the age groups.

Table 3. Susceptibility of mice of different age groups on intracerebral inoculation with Type $I$, adapted poliomyelitis virus

$\begin{array}{cccc}\begin{array}{c}\text { Age of mice } \\ \text { in days }\end{array} & \begin{array}{c}\text { No. of mice } \\ \text { inoculated }\end{array} & \begin{array}{c}\text { No. of mice } \\ \text { paralysed } \\ \text { after } 2 \text { days }\end{array} & \begin{array}{c}\text { Titre of } \\ \text { CNS mice* }\end{array} \\ 2 & 13 & 0 & - \\ 4 & 12 & 1 & - \\ 6 & 16 & 14 & 10^{6} \\ 8 & 20 & 16 & 10^{5.5} \\ 10 & 18 & 16 & 10^{7.0} \\ 12 & 19 & 19 & 10^{6.5} \\ 14 & 15 & 10 & 10^{6.0} \\ 16 & 14 & 10 & 10^{6.0} \\ 18 & 28 & 27 & 10^{6.0} \\ * \text { Virus titre expressed as number of } \text { TCID }_{50} / \text { ml. of } 10 \% \text { brain emulsion. }\end{array}$

That the paralysis in the mice of the later passages was due to Type I virus was confirmed by the demonstration of complete neutralization of the virus present on testing with the Type 1 monkey immune serum.

\section{DISCUSSION}

When the Mahoney, Type 1 poliomyelitis virus, previously adapted to adult mice by repeated intraspinal and later intracerebral passage, is inoculated intracerebrally into suckling mice aged 4-5 days two cycles of multiplication of the virus occur. The first takes place $48 \mathrm{hr}$. after inoculation of the virus and is unassociated with paralysis; the second occurs when the mice are 10-14 days older and this is associated with paralysis of either fore- or hindlimbs, or both. Passage of the virus in brains and cords of mice paralysed late into further sucklings will again result in paralysis when the mice are older. The multiplication which the unadapted virus can be shown to undergo, without eliciting symptoms, may be similar to the phenomenon of limited symptomless multiplication in the CNS of mice of bluetongue virus (van den Ende, Linder \& Kaschula, 1954) and influenza and Newcastle disease viruses (Cairns, 1951). 
The CNS of suckling mice paralysed within $48 \mathrm{hr}$. after inoculation of virus adapted to mice of this age, and containing abundant virus detectable by tissue culture methods, however, repeatedly fails to produce paralysis in a significant proportion of sucklings on subinoculation, unless the alternate tissue culture passage is employed.

The amount of virus present in the inoculum appears to have an influence on the effect produced in suckling mice. Thus virus from tissue culture during the earlier passages almost invariably had a higher titre than that obtained from suspensions of brain and cord. Tissue culture virus with an infective titre of $10^{6}$ or more per ml. regularly elicited early paralysis in a high percentage of recipient mice. The same material diluted a hundred-fold (Table 2) produced paralysis in an insignificant number of mice. The latter inoculum, nevertheless, resulted in early 'silent' multiplication of virus in the CNS (Fig. $2 B$ ).

After successful adaptation to sucklings, brain suspensions were obtained with virus titres of $10^{6.0}$ and higher, and these were able to produce early paralysis in about $35 \%$ of mice without intermediate tissue culture passage. Nevertheless, on further mouse-to-mouse passage the incidence of paralysis rapidly diminished.

The titre of the inoculum is therefore an important factor in eliciting paralysis, but it can further be postulated that there are at least two variants of the virus. This may be analogous to the phenomenon observed by Schlesinger \& Frankel (1952) with dengue fever virus. In suckling mouse brains the multiplication of the Mahoney Type 1 poliomyelitis virus results in the production of predominantly the non-paralytic variant, which can, however, be detected by the characteristic cytopathogenic effect produced in tissue culture. Tissue culture, on the other hand, favours the free multiplication of both paralytic and non-paralytic variants. In suckling mouse brain the non-paralytic variant tends to multiply selectively unless the original inoculum contains enough paralytic variant to cause eariy paralysis. This would appear to be the explanation why alternate mouse-tissue culture passage will produce paralysis in a high proportion of suckling mice, whilst mouse-to-mouse passage fails to do so, even when the titre of the inocula are the same.

Attempts to separate out the paralytic variant by limit dilution of the virus in tissue culture, so that it is the predominant virus, have thus far not been successful.

Further work is in progress to attempt to isolate the paralytic variant by a prolonged series of alternate mouse-tissue culture passages, and to demonstrate the postulated selective production of non-paralytic virus in sucklings receiving inocula of material not completely adapted to the suckling mouse. The findings may be of significance in the preparation of vaccines for use in man.

\section{SUMMARY}

The Mahoney, Type I, poliomyelitis virus undergoes two 'cycles' of multiplication in the CNS of suckling mice-the first within $48 \mathrm{hr}$. after intracerebral inoculation, and the second approximately 10 days later. The former may not be associated with paralysis whilst the latter usually is. 
By to-and-fro passage in suckling mouse brain and monkey kidney-tissue culture there is a gradual increase in the amount of virus obtained during the early multiplication cycle in suckling mouse brains and associated with this is the occurrence of early paralysis in $80 \%$ or more of these mice. The virus capable of causing early paralysis in infant mice is gradually lost by direct mouse-to-mouse passage.

The occurrence of two variants is postulated, one of these apparently nonparalytic and multiplying selectively in suckling brains.

The author would like to thank the late Prof. M. van den Ende for his stimulating discussions and advice, Dr P. K. Olitsky of New York for his constant interest, and Mr T. C. Norcott for his able technical assistance.

\section{REFERENCES}

Carrns, H. J. F. (1951). The growth of influenza viruses and Newcastle disease virus in mouse brain. Brit. J. exp. Path. 32, 110.

Melnick, J. L., Rappaport, C., Banker, D. D. \& Bhatt, P. N. (1955). Stabilized suspension of monkey kidney cells suitable for intercontinental shipment. Proc. Soc. exp. Biol., N.Y., 88, 678 .

Schlesinger, R. W. \& Frankel, J. W. (1952). Interference as a factor in the adaptation to mice of a strain of dengue virus. Bact. Proc. Soc. Amer. Bact. p. 85.

Selzer, G., SaCKs, M. \& VAN DEN ENDe, M. (1952). Adaptation and multiplication rate of the $\mathrm{MEF}_{1}$ strain of poliomyelitis in new-born mice. S. Afr. med.J. 26, 201.

vax den Ende, M., Linder, A. M. \& Kaschula, V. R. (1954). Experiments with the Cyprus strain of bluetongue virus: multiplication in the CNS of mice and complement fixation. J. Hyg., Camb., 52, 155.

(MS. received for publication 13. XI. 56) 